\title{
Effect of a Coadsorbent on the Performance of Dye-Sensitized TiO2 Solar Cells: Shielding versus Band-Edge Movement
}

Conference Paper NREL/CP-590-38978

November 2005

\author{
A.J. Frank, N.R. Neale, N. Kopidakis, and \\ J. van de Lagemaat
}

National Renewable Energy Laboratory

M. Grätzel

Swiss Federal Institute of Technology

Presented at the 2005 DOE Solar Energy Technologies Program Review Meeting

November 7-10, 2005

Denver, Colorado

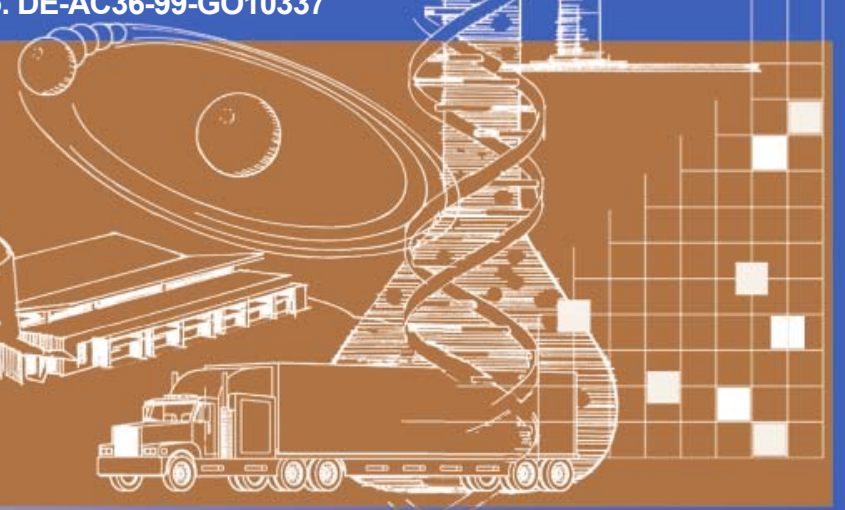




\section{NOTICE}

The submitted manuscript has been offered by an employee of the Midwest Research Institute (MRI), a contractor of the US Government under Contract No. DE-AC36-99G010337. Accordingly, the US Government and MRI retain a nonexclusive royalty-free license to publish or reproduce the published form of this contribution, or allow others to do so, for US Government purposes.

This report was prepared as an account of work sponsored by an agency of the United States government. Neither the United States government nor any agency thereof, nor any of their employees, makes any warranty, express or implied, or assumes any legal liability or responsibility for the accuracy, completeness, or usefulness of any information, apparatus, product, or process disclosed, or represents that its use would not infringe privately owned rights. Reference herein to any specific commercial product, process, or service by trade name, trademark, manufacturer, or otherwise does not necessarily constitute or imply its endorsement, recommendation, or favoring by the United States government or any agency thereof. The views and opinions of authors expressed herein do not necessarily state or reflect those of the United States government or any agency thereof.

Available electronically at http://www.osti.gov/bridge

Available for a processing fee to U.S. Department of Energy and its contractors, in paper, from:

U.S. Department of Energy

Office of Scientific and Technical Information

P.O. Box 62

Oak Ridge, TN 37831-0062

phone: 865.576.8401

fax: 865.576 .5728

email: mailto:reports@adonis.osti.gov

Available for sale to the public, in paper, from:

U.S. Department of Commerce

National Technical Information Service

5285 Port Royal Road

Springfield, VA 22161

phone: 800.553 .6847

fax: 703.605.6900

email: orders@ntis.fedworld.gov

online ordering: http://www.ntis.gov/ordering.htm 


\title{
Effect of a Coadsorbent on the Performance of Dye-Sensitized $\mathrm{TiO}_{2}$ Solar Cells: Shielding versus Band-Edge Movement
}

\author{
Arthur J. Frank, ${ }^{1}$ Nathan R. Neale, ${ }^{1}$ Nikos Kopidakis, ${ }^{1}$ Jao van de Lagemaat, ${ }^{1}$ and Michael Grätzel ${ }^{2}$ \\ ${ }^{1}$ National Renewable Energy Laboratory, Golden, Colorado, arthur_frank@nrel.gov \\ ${ }^{2}$ Swiss Federal Institute of Technology, Lausanne, Switzerland
}

\begin{abstract}
The objective of this research is to determine the operational characteristics key to efficient, low-cost, stable solar cells based on dye-sensitized mesoporous films (in collaboration with DOE's Office of Science Program). Toward this end, we have investigated the mechanism by which the adsorbent chenodeoxycholate, cografted with a sensitizer onto $\mathrm{TiO}_{2}$ nanocrystals, improves the open-circuit photovoltage $\left(V_{O C}\right)$ and short-circuit photocurrent density $\left(J_{\mathrm{SC}}\right){ }^{1}{ }^{1}$ We find that adding chenodeoxycholate not only shifts the $\mathrm{TiO}_{2}$ conduction-band edge to negative potentials but also accelerates the rate of recombination. The net effect of these opposing phenomena is to produce a higher photovoltage. It is also found that chenodeoxycholate reduces the dye loading significantly but has only a modest effect on $J_{\text {sc. }}$ Implications of these results to developing more efficient cells are discussed.
\end{abstract}

\section{Objectives}

The dye-sensitized solar cell (DSC) is a promising future generation concept for achieving efficient solarto-electric energy conversion with very inexpensive materials and manufacturing processes. These cells feature dye molecules chemisorbed on the surface of $\mathrm{TiO}_{2}$ nanocrystals that have been sintered into a highly porous thin film. The pores of the film are filled with a hole-conducting electrolyte. Photoexcited dye molecules inject electrons into the conduction band of $\mathrm{TiO}_{2}$, and species in the electrolyte transport the holes from the oxidized dye molecules to the counter electrode. While $J_{\mathrm{SC}}$ is mostly controlled by the lightharvesting and charge-injection efficiencies of the dye, $V_{O C}$ is determined by the difference between the quasiFermi level of electrons in the $\mathrm{TiO}_{2}$ film and the energy of the redox couple in the electrolyte.

Over the past decade, numerous studies have reported that chemically treating the $\mathrm{TiO}_{2}$ surface with certain organic molecules influences the photovoltage and/or the photocurrent. Passivation or shielding of recombination centers by adsorbed molecules is generally given as the explanation for the observed effect. However, there is evidence that adsorbed molecules can improve the cell performance by inducing band-edge movement. ${ }^{2}$ In most studies, the proposed mechanism for the improved cell performance is based on measurements that do not distinguish between shielding and band-edge movement. To devise more effective surface treatment strategies, it is critical to understand the mechanism by which the surface treatment affects cell performance. In this paper, we examine the basic physical processes by which the adsorbent, chenodeoxycholate, affects $V_{\mathrm{OC}}$ and $J_{\mathrm{SC}}$ in dyesensitized solar cells. ${ }^{1}$ Chenodeoxycholate is a cholesterol-based molecule that has been shown to improve $J_{\mathrm{SC}}$ and $V_{\mathrm{OC}}$.

Understanding the fundamental phenomena governing cell performance is critical for underpinning the development of this new solar cell technology. Of programmatic importance is that sensitized nanoparticle solar cells represent the distinct technological promise for achieving mass-produced, ultra-low-cost solar panels with good efficiency.

\section{Technical Approach}

$J-V$ measurements combined with optical absorption studies of dye desorption were used to evaluate the influence of tetrabutylammonium chenodeoxycholate on dye coverage, binding strength of dye, extent of dye aggregation, and $J_{\mathrm{SC}}$ under a variety of conditions in which the $\mathrm{TiO}_{2}$ films were exposed to the coadsorbent and sensitizing dye $\mathrm{TBA}_{2}\left[\mathrm{RuL}_{2}(\mathrm{NCS})_{2}\right] \quad(\mathrm{L}=$ 4-carboxylic acid-4'carboxylate-2,2'-bipyridine; TBA = tetrabutylammonium). These measurements and associated calculations were performed to quantify the relationship of dye coverage to the light-harvesting efficiency of the cells. Measurements of $V_{O C}$ as a function of the photocharge density (determined by infrared transmittance) were conducted to determine whether the changes in $J_{\mathrm{SC}}$ and $V_{\mathrm{OC}}$ (resulting from surface treatment) were caused by altering the band edge position and/or the rate of recombination.

\section{Results and Accomplishments}

The influence of chenodeoxycholate on dye loading was investigated under a variety of conditions in which the $\mathrm{TiO}_{2}$ film was exposed to the sensitizing dye and coadsorbent. J-V measurements and desorption studies revealed that adding chenodeoxycholate reduces the dye loading by as much as $60 \%$ while having a relatively small effect on $J_{\text {sc }}$. While twice exposing a $\mathrm{TiO}_{2}$ film to dye solution had no effect on the amount of dye coverage relative to a single exposure, the resulting dye layer was more resistant to displacement by chenodeoxycholate. These observations suggest that single dyeing of a $\mathrm{TiO}_{2}$ film 
leads to strongly and weakly adsorbed forms of the dye resulting from either different binding conformations or aggregates. A comparison of adsorption conditions revealed that although chenodeoxycholate reduced the dye coverage by about $60 \%, J_{\text {Sc }}$ decreased by only $14 \%$, from 13.2 to $11.4 \mathrm{~mA} \mathrm{~cm}{ }^{-2}$. Calculations using the Beer-Lambert Law along with measurements suggest that even at low loading enough dye is present to account for the otherwise surprisingly small drop in $J_{\mathrm{SC}}$.

Figure 1 shows that at the same photoinduced charge density $\left(1.5 \times 10^{17} \mathrm{~cm}^{-3}\right)$ the photovoltage of the cell with the dye and chenodeoxycholate-covered film was about $80 \mathrm{mV}$ higher than that of the cell with a film exposed to just the dye. This result indicates that the adsorbent causes the $\mathrm{TiO}_{2}$ bands to move upward by about $80 \mathrm{mV}$.

Figure 2 shows that at the same photocharge density, the recombination rate for the cell with chenodeoxycholate was five times higher than that for the cell without chenodeoxycholate. At constant photocharge density, an upward shift of the conduction band edge (Figure 1) would be expected to increase the rate of recombination (Figure 2) because the driving force for recombination is determined by the difference between the electron quasi-Fermi level and the electrochemical potential of the electrolyte. These measurements along with $J-V$ data indicate that the net increase of $V_{O C}$ as a result of both band-edge movement and recombination was more than $40 \mathrm{mV}$ and that recombination diminished the effect of bandedge movement on $V_{\text {OC }}$ by more than $40 \mathrm{mV}$.

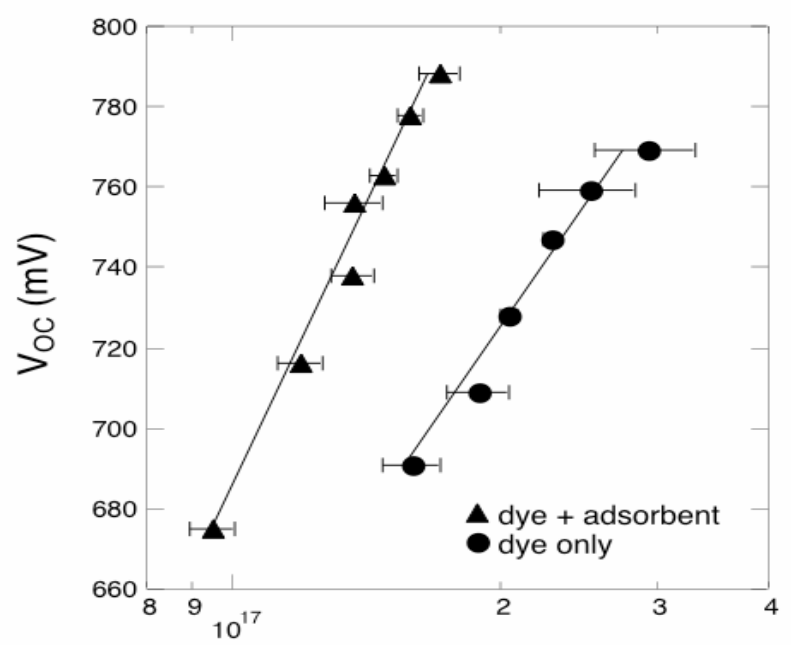

Photocharge density at open circuit $\left(\mathrm{cm}^{-3}\right)$

Fig. 1. Effect of chenodeoxycholate on the $\mathrm{TiO}_{2}$ bandedge position. ${ }^{1}$

\section{Conclusions}

The coadsorbent chenodeoxycholate is found to reduce the dye loading by about half but to have a disproportionately small effect on $J_{\text {SC. }}$. Calculations reveal that even at such low dye loading enough dye

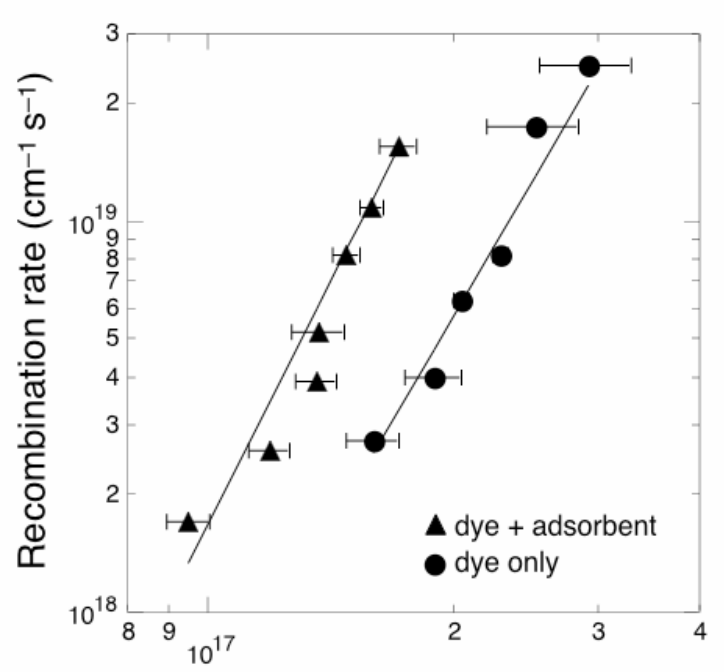

Photocharge density at open circuit $\left(\mathrm{cm}^{-3}\right)$

Fig. 2. Effect of chenodeoxycholate on the rate of recombination. ${ }^{1}$

was present to absorb a significant fraction of incident light. Chenodeoxycholate is found to not only shift the band edges to negative potentials, but also to significantly increase the recombination rate. The net effect of adding chenodeoxycholate is, however, to improve the photovoltage. Future work will utilize the information from this study to devise a more effective surface treatment strategy for improved cell efficiency.

\section{ACKNOWLEDGEMENTS}

The NREL work was performed under DOE contract DE-AC36-99-G010337.

\section{REFERENCES}

${ }^{1}$ N. R. Neale, N. Kopidakis, J. van de Lagemaat, M. Grätzel, and A. J. Frank, J. Phys. Chem. B., in press. ${ }^{2}$ G. Schlichthörl, S. Huang, J. Sprague, and A. J. Frank, J. Phys. Chem. B 101, 8141 (1997).

\section{MAJOR FY 2005 PUBLICATIONS}

N. Kopidakis, N. R. Neale, K. Zhu, J. van de Lagemaat and A. J. Frank, "Spatial Location of Transport-Limiting Traps in $\mathrm{TiO}_{2}$ Nanoparticle Films in Dye-Sensitized Solar Cells," Appl. Phys. Lett., in press.

N. Kopidakis, K. D. Benkstein, J. van de Lagemaat, A. J. Frank, Q. Yuan and E. A. Schiff, "Temperature Dependence of the Electron Diffusion Coefficient in Electrolyte-Filled $\mathrm{TiO}_{2}$ Nanoparticle Films: Evidence Against Multiple Trapping In Exponential Conduction Band Tails," Phys. Rev. B., submitted.

J. van de Lagemaat, N. Kopidakis, N. R. Neale, and A. J. Frank, "Effect of Nonideal Statistics on Electron Diffusion in Sensitized Nanocrystalline $\mathrm{TiO}_{2}$," Phys. Rev. B. 71, 035304 (2005). 


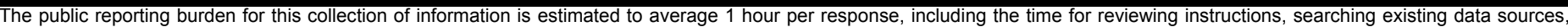

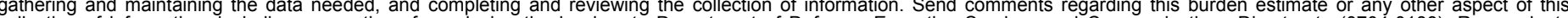

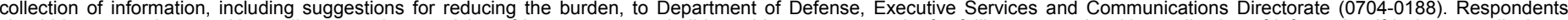

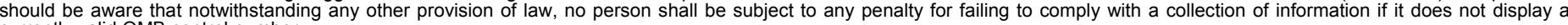
currently valid OMB control number.

PLEASE DO NOT RETURN YOUR FORM TO THE ABOVE ORGANIZATION.

\section{REPORT DATE (DD-MM-YYYY) November 2005}

4. TITLE AND SUBTITLE

Effect of a Coadsorbent on the Performance of Dye-Sensitized TiO2 Solar Cells: Shielding versus Band-Edge Movement
3. DATES COVERED (From - To)

5a. CONTRACT NUMBER

DE-AC36-99-G010337

5b. GRANT NUMBER

5c. PROGRAM ELEMENT NUMBER

5d. PROJECT NUMBER

NREL/CP-590-38978

5e. TASK NUMBER

PVA6.0603

5f. WORK UNIT NUMBER

7. PERFORMING ORGANIZATION NAME(S) AND ADDRESS(ES)

National Renewable Energy Laboratory

1617 Cole Blvd.

REPORT NUMBER

Golden, CO 80401-3393

NREL/CP-590-38978

9. SPONSORING/MONITORING AGENCY NAME(S) AND ADDRESS(ES)

10. SPONSOR/MONITOR'S ACRONYM(S) NREL

11. SPONSORING/MONITORING AGENCY REPORT NUMBER

\section{DISTRIBUTION AVAILABILITY STATEMENT}

National Technical Information Service

U.S. Department of Commerce

5285 Port Royal Road

Springfield, VA 22161

\section{SUPPLEMENTARY NOTES}

\section{ABSTRACT (Maximum 200 Words)}

The objective of this research is to determine the operational characteristics key to efficient, low-cost, stable solar cells based on dye-sensitized mesoporous films (in collaboration with DOE's Office of Science Program). Toward this end, we have investigated the mechanism by which the adsorbent chenodeoxycholate, cografted with a sensitizer onto $\mathrm{TiO}_{2}$ nanocrystals, improves the open-circuit photovoltage $\left(V_{\mathrm{OC}}\right)$ and short-circuit photocurrent density $\left(J_{\mathrm{SC}}\right) .{ }^{1} \mathrm{We}$ find that adding chenodeoxycholate not only shifts the $\mathrm{TiO}_{2}$ conduction-band edge to negative potentials but also accelerates the rate of recombination. The net effect of these opposing phenomena is to produce a higher photovoltage. It is also found that chenodeoxycholate reduces the dye loading significantly but has only a modest effect on $J_{\mathrm{Sc}}$. Implications of these results to developing more efficient cells are discussed.

\section{SUBJECT TERMS}

Photovoltaics; solar; coadsorbent; die-sensitized TiO2; PV; NREL

\begin{tabular}{|c|c|c|}
\hline \multicolumn{3}{|c|}{ 16. SECURITY CLASSIFICATION OF: } \\
\hline $\begin{array}{l}\text { a. REPORT } \\
\text { Unclassified }\end{array}$ & $\begin{array}{l}\text { b. ABSTRACT } \\
\text { Unclassified }\end{array}$ & $\begin{array}{l}\text { c. THIS PAGE } \\
\text { Unclassified }\end{array}$ \\
\hline
\end{tabular}

17. LIMITATION
OF ABSTRACT
UL

18. NUMBER
OF PAGES

\begin{tabular}{l} 
19a. NAME OF RESPONSIBLE PERSON \\
19b. TELEPONE NUMBER (Include area code) \\
\hline
\end{tabular}

